\title{
Investigations into the declining health of alder (Alnus glutinosa) along the river Lagan in Belfast, including the first report of Phytophthora lacustris causing disease of Alnus in Northern Ireland
}

\author{
Richard O Hanlon $(1,2) *$ Julia Wilson (2), Deborah Cox (1)
}

(1) Agri-Food and Biosciences Institute, Belfast, BT9 5PX, Northern Ireland, UK.

(2) Queen's University Belfast, Northern Ireland, UK

*publications@rohanlon.org

Additional key words: Plant health, Forest pathology, riparian, root and collar rot.

\begin{abstract}
Common alder (Alnus glutinosa) is an important tree species, especially in riparian and wet habitats. Alder is very common across Ireland and Northern Ireland, and provides a wide range of ecosystem services. Surveys along the river Lagan in Belfast, Northern Ireland led to the detection of several diseased Alnus trees. As it is known that Alnus suffers from a Phytophthora induced decline, this research set out to identify the presence and scale of the risk to Alnus health from Phytophthora and other closely related oomycetes. Sampling and a combination of morphological and molecular testing of symptomatic plant material and river baits identified the presence of several Phytophthora species, including Phytophthora lacustris. A survey of the tree vegetation along an $8.5 \mathrm{~km}$ stretch of the river revealed that of the 166 Alnus trees counted, 28 were severely defoliated/diseased and 9 were dead. Inoculation studies using potted Alnus saplings demonstrate that $P$. lacustris was able to cause disease, and Koch's postulates for this pathogen-host combination were completed, which suggests a future risk to Alnus health from P. lacustris in Northern Ireland.
\end{abstract}

\section{Introduction}

Common alder (Alnus glutinosa (L.) Gaertn.) is native to Europe, being common across Britain and Ireland (Clapham et al. 1952). Alder accounts for $2.7 \%$ of the forest estate in Ireland (NFI 2017), and is known as a relatively short lived tree (ca. 150 years; Mitchell 1996) that is suitable for planting in sites prone to water logging (Horgan et al. 2004). Native alder woods are common on wet poorly drained sites in Ireland, and can support a diverse herb and bryophyte layer (Cross 2012). Planting of Alnus in forests is supported in Ireland and Northern Ireland by government forestry grants (DAFM 2015; DAERA 2019). Furthermore, it has been suggested that introducing Alnus into plantations of Sitka spruce (Picea sitchensis) in Ireland and Britain would add structural diversity and have a positive effect on biodiversity and associated ecosystem services (Deal et al. 2014).

In 1993, a dieback of Alnus was noted in Britain, associated with a then unknown Phytophthora species (Gibbs et al. 1999). Further research identified the pathogen as being widespread in England and Wales (Streito 2003), and the pathogen was formally described as Phytophthora alni (Brasier et al. 2004). Phytophthora alni sensu lato was later split into three taxa, the species Phytophthora uniformis, and the hybrid species Phytophthora $\times$ multiformis and Phytophthora $\times$ alni based on molecular analysis (Husson et al. 2015). Dieback of alder 
caused by these pathogens has now been recorded in 17 European countries (Bjelke et al. 2016). Alder dieback was first confirmed in Ireland in 1999 (Clancy and Hamilton 1999), associated with Phytophthora $\times$ multiformis (O Hanlon et al. 2016a), while findings of alder dieback associated with $P$. uniformis were made in 2016 (O Hanlon et al. 2016b). To date, none of the previously mentioned pathogens have been detected in Northern Ireland $(\mathrm{O}$ Hanlon et al. 2016a), although dieback symptoms on alder have been evident for several years. For example, images on the free online resource Google street view from July 2008 to July 2018 show signs of alder dieback (e.g. thinning crown, bleeding cankers on the trunk, tree mortality) along the river Lagan in Belfast Northern Ireland UK (Figure 1). Haphazard surveys of the river bank of the Lagan close to the Agri-Food and Biosciences Institute headquarters in Newforge lane, Belfast have also identified Alnus trees with symptoms of Phytophthora infection (Fig. 2). Symptoms include thinning foliage composed of small yellowing leaves, and bleeding cankers on the trunk, similar to the symptoms normally caused by other tree infecting Phytophthora species (Jung et al. 2018).

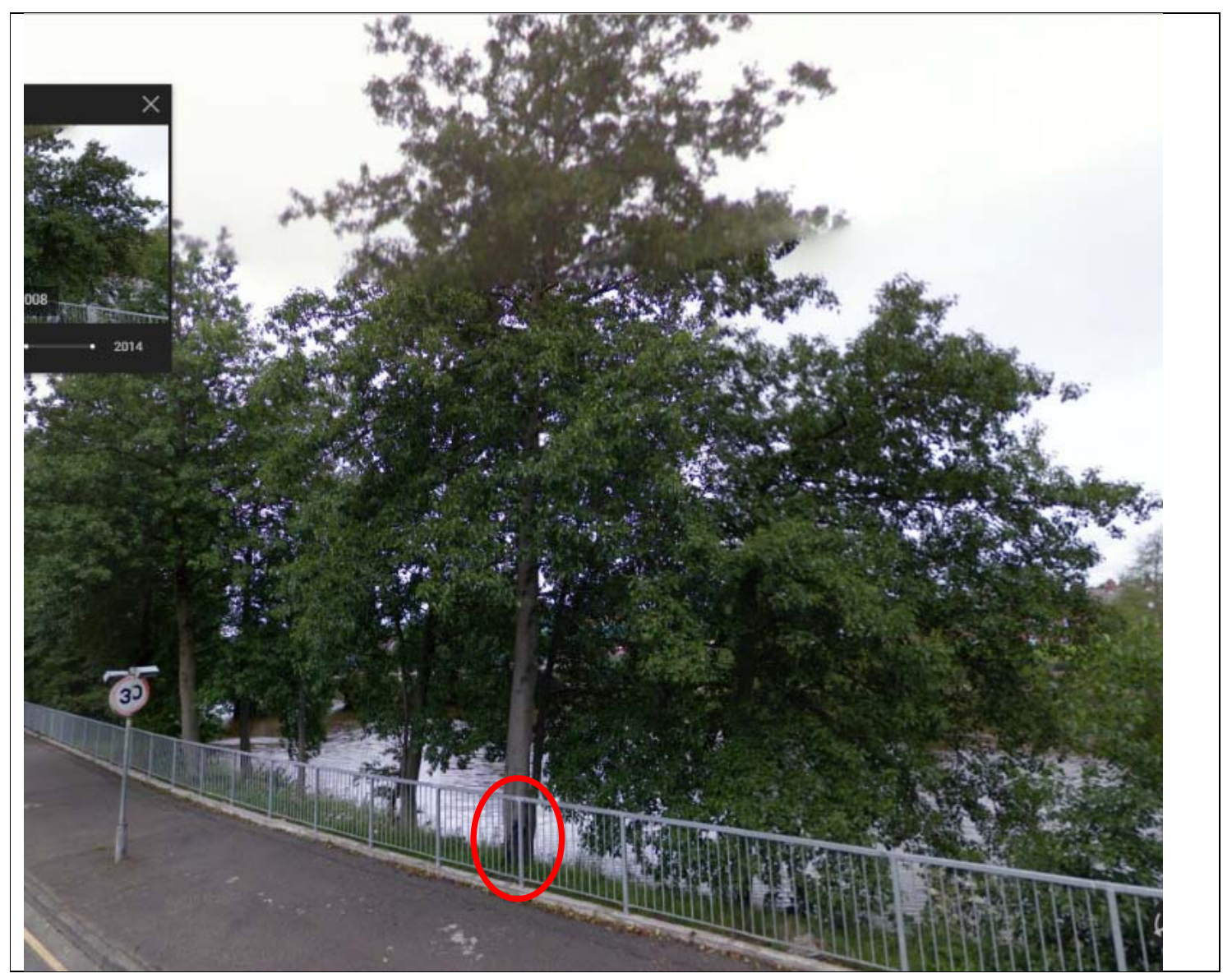


bioRxiv preprint doi: https://doi.org/10.1101/2019.12.13.875229; this version posted December 13, 2019. The copyright holder for this preprint (which was not certified by peer review) is the author/funder, who has granted bioRxiv a license to display the preprint in perpetuity. It is made available under aCC-BY-NC 4.0 International license.

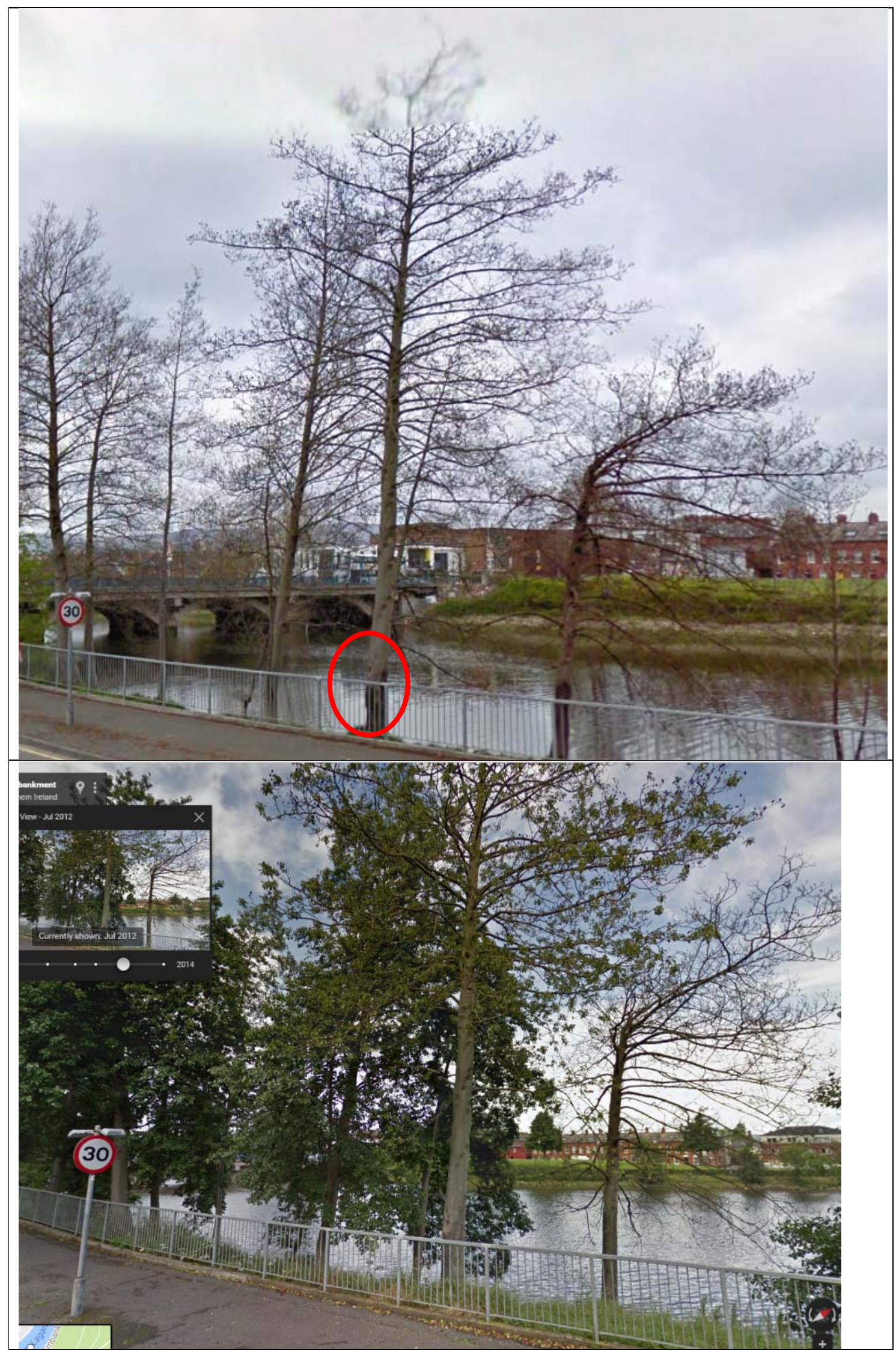


bioRxiv preprint doi: https://doi.org/10.1101/2019.12.13.875229; this version posted December 13, 2019. The copyright holder for this preprint (which was not certified by peer review) is the author/funder, who has granted bioRxiv a license to display the preprint in perpetuity. It is made available under aCC-BY-NC 4.0 International license.

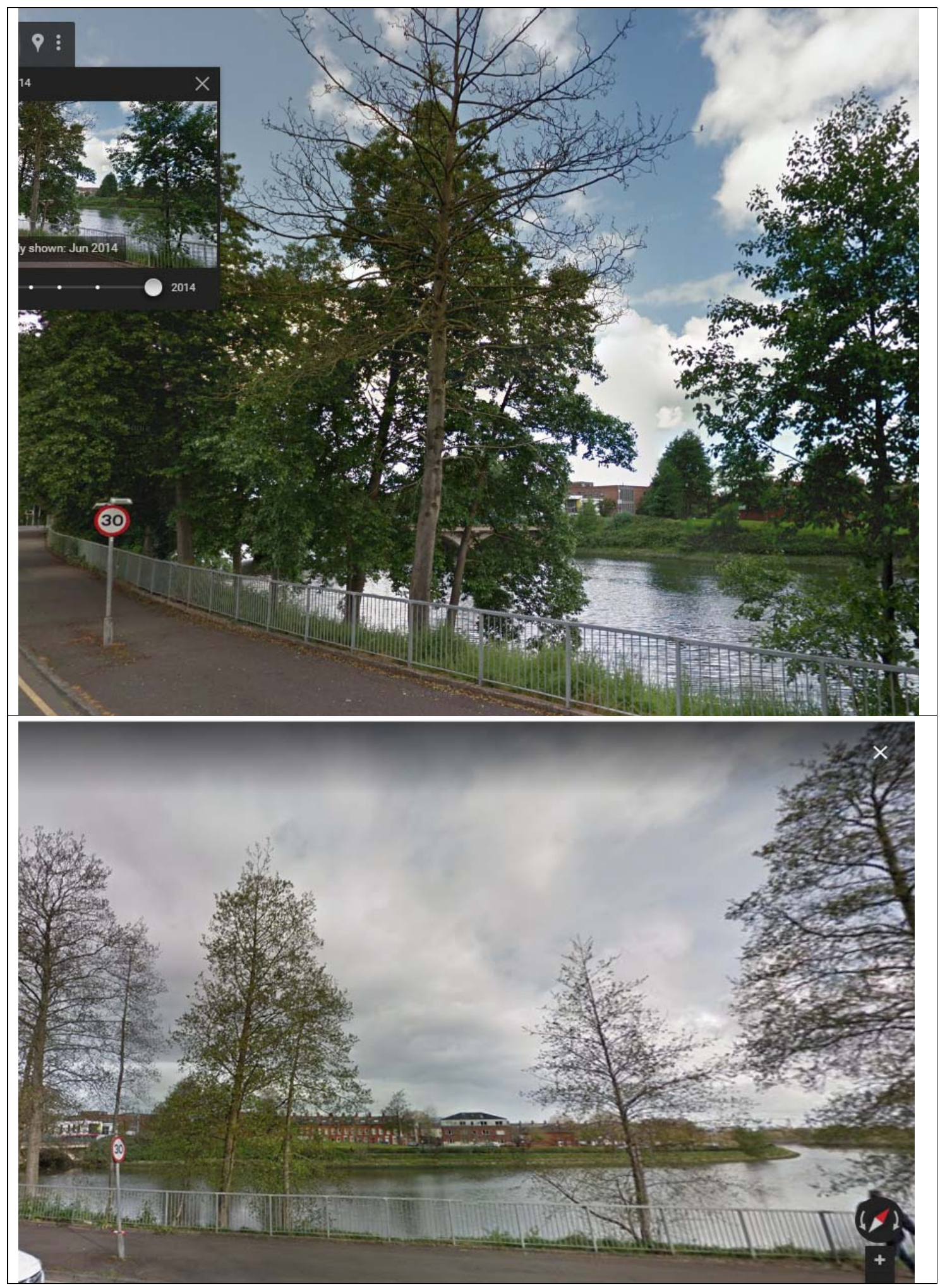




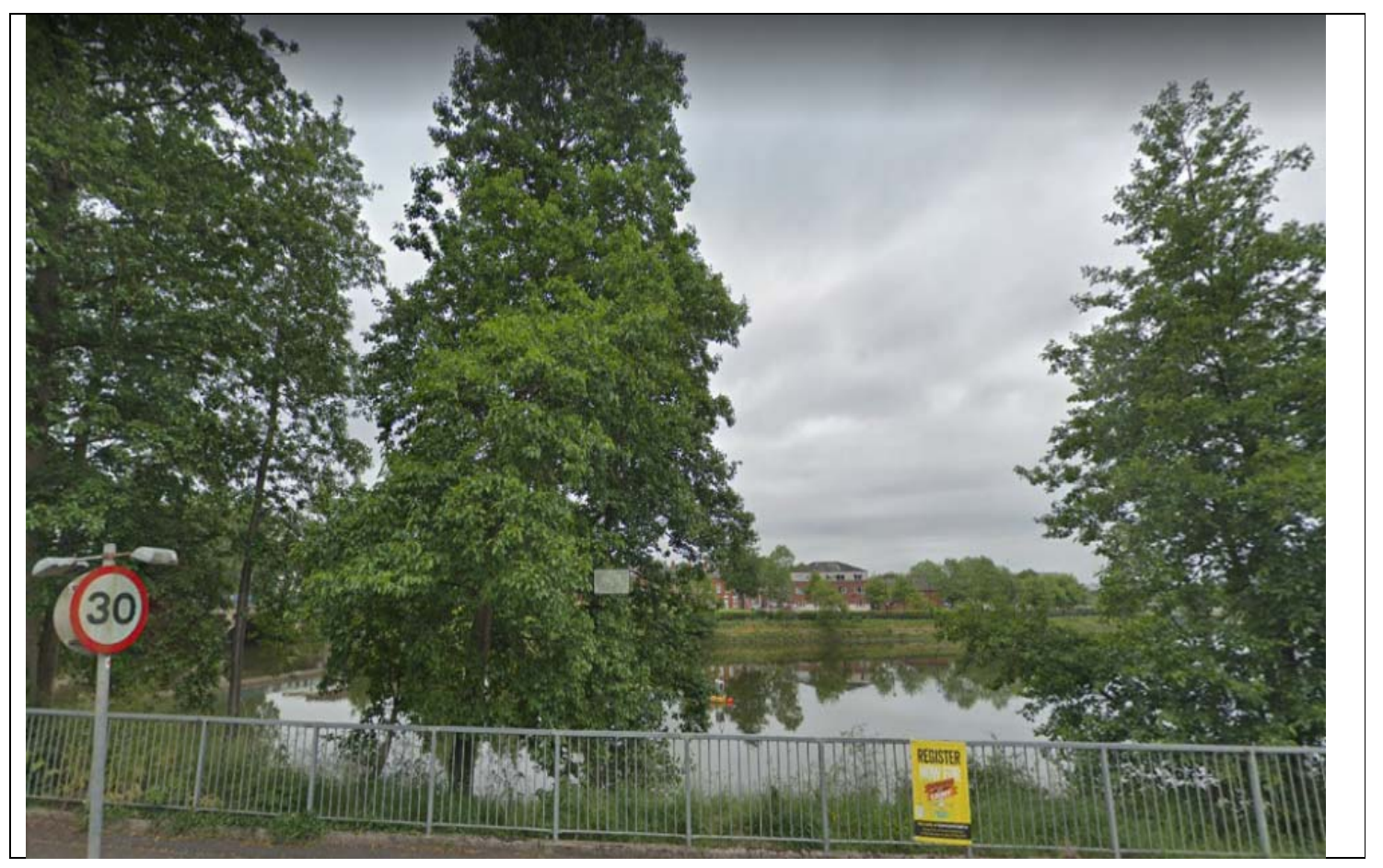

Figure 1 (composite) Chronosequence of Google street view images showing symptoms of alder dieback along the river Lagan in Belfast, Northern Ireland (54³4'58.1"N, $\left.5^{\circ} 55^{\prime} 12.8^{\prime \prime}\right)$. The images were taken in different months, starting from top to bottom: July 2008, April 2010, July 2012, June 2014, April 2017, and July 2018. Areas showing typical Phytophthora bleeding cankers have been encircled in a red oval. 
bioRxiv preprint doi: https://doi.org/10.1101/2019.12.13.875229; this version posted December 13,2019 . The copyright holder for this preprint (which was not certified by peer review) is the author/funder, who has granted bioRxiv a license to display the preprint in perpetuity. It is made available under aCC-BY-NC 4.0 International license.

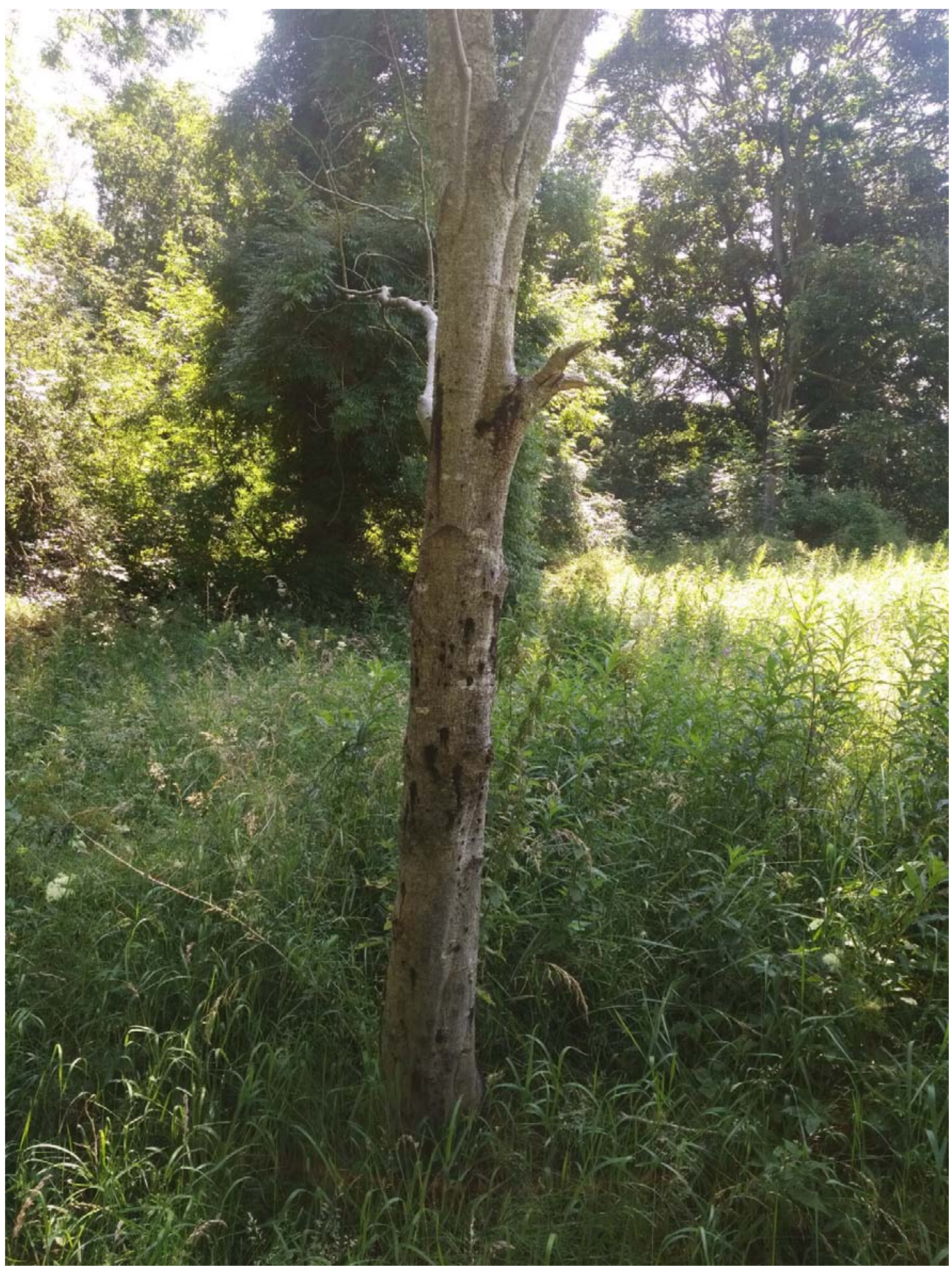

Figure 2: Bleeding cankers on Alnus glutinosa tree from which Phytophthora lacustris isolate $\mathrm{P} 17-120$ was isolated 
The aim of this research was to investigate the health status of Alnus along the river Lagan, and to assess if Phytophthora species were impacting on Alnus health. This was assessed by (i) testing symptomatic trees for Phytophthora infection, (ii) conducting live plant inoculation studies to confirm the pathogenicity of Phytophthora lacustris to Alnus glutinosa, (iii) sampling the river using leaf baiting to identify if Phytophthora species were present in the water and (iv) carrying out an Alnus health survey along a portion of the river.

\section{Methods}

\section{Symptomatic tree sampling and testing}

In 2018, bark samples $1 \mathrm{~cm}$ think (including the cambium) from the upper and lower limits of bleeding cankers on a single dead A. glutinosa tree (Fig. 2; 54 $333^{\prime} 26.9^{\prime \prime N} 5^{\circ} 56^{\prime} 10.7 " \mathrm{~W}$ ) were taken. Samples were surface sterilized and processed according to O Hanlon et al (2016b). Briefly, samples were put onto P5ARP $[\mathrm{H}]$ agar (1 litre distilled water, 17g cornmeal agar, 10 mg Pimiricin, $250 \mathrm{mg}$ Ampicillin, $10 \mathrm{mg}$ Rifamycin, $100 \mathrm{mg}$ PCNB; Jeffers \& Martin, 1986) and incubated at room temperature $\left(19^{\circ} \mathrm{C}\right)$ for up to 2 weeks. After 3 days incubation at $19^{\circ} \mathrm{C}$, Phytophthora-like mycelium was sub-cultured onto carrot piece agar (Werres et al. 2001) and incubated for another 5 days at $19^{\circ} \mathrm{C}$. The isolate (P17-120) was stored in culture at $4{ }^{\circ} \mathrm{C}$ for use in pathogenicity testing.

\section{Water baiting methods}

At 2 points along the Lagan, leaf bait bags were deployed according to Turner et al., (2006) and O'Hanlon et al. (2018) with minor modification as follows: A leaf of Alnus glutinosa, Rhododendron ponticum, and Quercus petraea was removed from live, symptomless (i.e. putatively disease free) plants on the day of baiting, and sealed into a bait bag. The bait bag was composed of a double layer of muslin cloth, which was stapled shut, tied to the river bank with fishing line, and dropped into the river and left to float in the current. Bait bags were collected after 1 week, returned to the lab and the leaves removed from the bag. The leaves were processed in a similar way to the symptomatic tree samples (above). Phytophthora-like isolates produced from baits were grouped into morphogroups based on colony morphology and spore dimensions (Gallegly \& Hong, 2008). When sporangia did not form on carrot piece agar, pieces of the outer colony edge were cut from the agar and put into a clean petri dish, and flooded with non-sterile pond water (i.e. a mixture of $50 \%$ water from the river Lagan and 50\% tap water) to induce spore formation according to Scanu et al. (2015). The pond water was $>6$ months old at the time, in order to provide some assurance that any Phytophthora spores that may have been in the water were dead. Zappia et al. (2014) review oomycete risks from water and indicate that in general, survival for more than a few days is uncommon. A representative of each morphogroup was identified by DNA sequencing of the ITS gene region using the primers ITS4 and ITS5 primers (White et al. 1990). The DNA sequence was checked against the database of curated Phytophthora sequences in PhytophthoraID (Grünwald, et al. 2011), and also against the uncurated reference database available in GenBank using the Basic Local Alignment Search Tool (BLAST) (Altschul et al. 1990). The isolate from the symptomatic Alnus tree (P17-120) was deposited in GenBank under the accession number MH784622. 


\section{Pathogenicity testing}

Potted seedlings of alder ( $<3$ years old) that were visually disease free were purchased from Coillte nurseries in Co Carlow, of which 12 were inoculated with agar plugs taken from the edge of the $P$. lacustris colony (P17-120) growing on carrot agar. Five other seedlings were inoculated with sterile carrot agar plugs to act as a negative control. In July 2018, each plant was wounded with a $3 \mathrm{~cm}$ cut into the bark approximately halfway up the stem, with the agar plug inserted into the cut and sealed with damp cotton wool and parafilm. The plants were kept outside in a dedicated experimental area and watered regularly. After 6 weeks the outer bark was carefully scraped off and the lesions examined and measured. Data on lesion lengths and treatment was plotted and compared for differences between treatments (inoculation vs control) according to the method of Ho et al. (2019) using the online tool available at https://www.estimationstats.com. The entire diseased area in each plant was removed with a sterile knife, and transferred to the laboratory for Phytophthora isolation as per above methodology.

\section{Riparian tree visual survey}

In order to investigate the extent of potential Alnus decline along the river, a visual survey of tree conditions was carried out along an $8.5 \mathrm{~km}$ stretch of the river. Mortality (dead, living), the level crown defoliation class ( $1=$ low defoliation, $4=$ extensive defoliation; Lakatos et al. 2014), age group ( $1=$ Diameter at Breast Height $(\mathrm{DBH})<10 \mathrm{~cm}, 2=\mathrm{DBH} 10-20,3=\mathrm{DBH}$ $>20$ ) and the presence of cankers for every Alnus tree was recorded. Notes were also taken of other tree health aspects for the surveyed Alnus trees. In order to get a rough estimation of the other tree species present in the area, the neighbouring species of tree to the left and right each Alnus tree was also recorded, if that tree was not also an Alnus.

\section{Results}

\section{Symptomatic plant sampling}

The isolate (P17-120) from the symptomatic Alnus tree was fast growing and produced a petaloid colony morphology similar to Phytophthora gonapodyides. The isolate produced non-caducous, non-papillate, mainly ovoid (some obpyriform) sporangia (average $35 \times 25$ $\mu \mathrm{m})$. Sporangia showed internal and external proliferation and often had wide exit pores. These characteristics are in line with the description of P. lacustris (Nechwatal et al. 2013). Comparison of the DNA sequence from this isolate with PhytophthoraID indicated that the isolate was a close match (99\%) to Phytophthora lacustris (Table 1).

Table 1 Results of the DNA sequencing of representative isolates of each of the morphogroups.

\begin{tabular}{|l|l|l|l|}
\hline \multicolumn{1}{|c|}{ Sample } & \multicolumn{1}{|c|}{$\begin{array}{c}\text { Best match } \\
\text { PhytophthoraID } \\
\text { (\% similarity) }\end{array}$} & \multicolumn{1}{|c|}{$\begin{array}{c}\text { Best match } \\
\text { GenBank } \\
\text { (\% similarity) }\end{array}$} & $\begin{array}{c}\text { No. isolates } \\
\text { collected }\end{array}$ \\
\hline $\begin{array}{l}\text { Symptomatic Alnus } \\
\text { canker (P17-120) }\end{array}$ & $\begin{array}{l}\text { Phytophthora lacustris } \\
(\text { 99) }\end{array}$ & P. lacustris (100) & 1 \\
\hline Baiting morphotype 1 & P. lacustris (99) & $\begin{array}{l}\text { Phytophthora } \\
\text { gonapodyides (96) / } \\
\text { P. lacustris (96) }\end{array}$ & 3 \\
\hline
\end{tabular}




\begin{tabular}{|l|l|l|l|}
\hline Baiting morphotype 2 & $\begin{array}{l}\text { Phytophthora } \\
\text { chlamydospora }(99)\end{array}$ & $\begin{array}{l}\text { P. chlamydospora } \\
(99) / P . \text { lacustris } \\
(99)\end{array}$ & 13 \\
\hline Baiting morphotype 3 & P. lacustris (97) & $\begin{array}{l}\text { P. lacustris }(97) / P . \\
\text { gonapodyides }(97)\end{array}$ & 91 \\
\hline Baiting morphotype 4 & Pythium vexans (80) & $\begin{array}{l}\text { Phytopythium } \\
\text { litorale (99) }\end{array}$ & 52 \\
\hline
\end{tabular}

\section{Leaf baiting}

Over 10 weeks of baiting, with weekly collections from 2 locations, 159 isolates were collected. These isolates were grouped into 4 morphogroups based on gross colony morphology, and spore microscopic characteristics. DNA sequencing indicated that these morphogroups represented 4 different taxa, although \% similarity between the isolates collected and those in the online databases varied (Table 1). In three cases (Morphotype 1, 2, 3 ) the isolates were equally similar to two different species in the Genbank database. Morphotype 3 was commonly isolated, with morphotype 1 only isolated on 3 occasions.

\section{Pathogenicity testing}

After 6 weeks dark lesions around the inoculation point were observed. The plants inoculated with P. lacustris isolate P17-120 had lesions of mean length $4.4 \mathrm{~cm}(\mathrm{n}=12, \mathrm{SD}+/-0.76)$ whereas control plants had lesions of mean length $3.42(n=5$, SD+/- 0.60) (Fig. 3). This difference in lesion size related to treatment was confirmed by a Mann Whitney $\mathrm{U}$ test $(\mathrm{U}=$ 51.5, $\mathrm{p}<0.05)$. Attempts to isolate Phytophthora from the wounding points on inoculated and control saplings were carried out, with P. lacustris (confirmed by morphology) re-isolated from the necrotic tissue from all of the inoculated trees. No Phytophthora cultures were isolated from control plants. This completes Koch's postulates for this host-pathogen pair in Northern Ireland. 


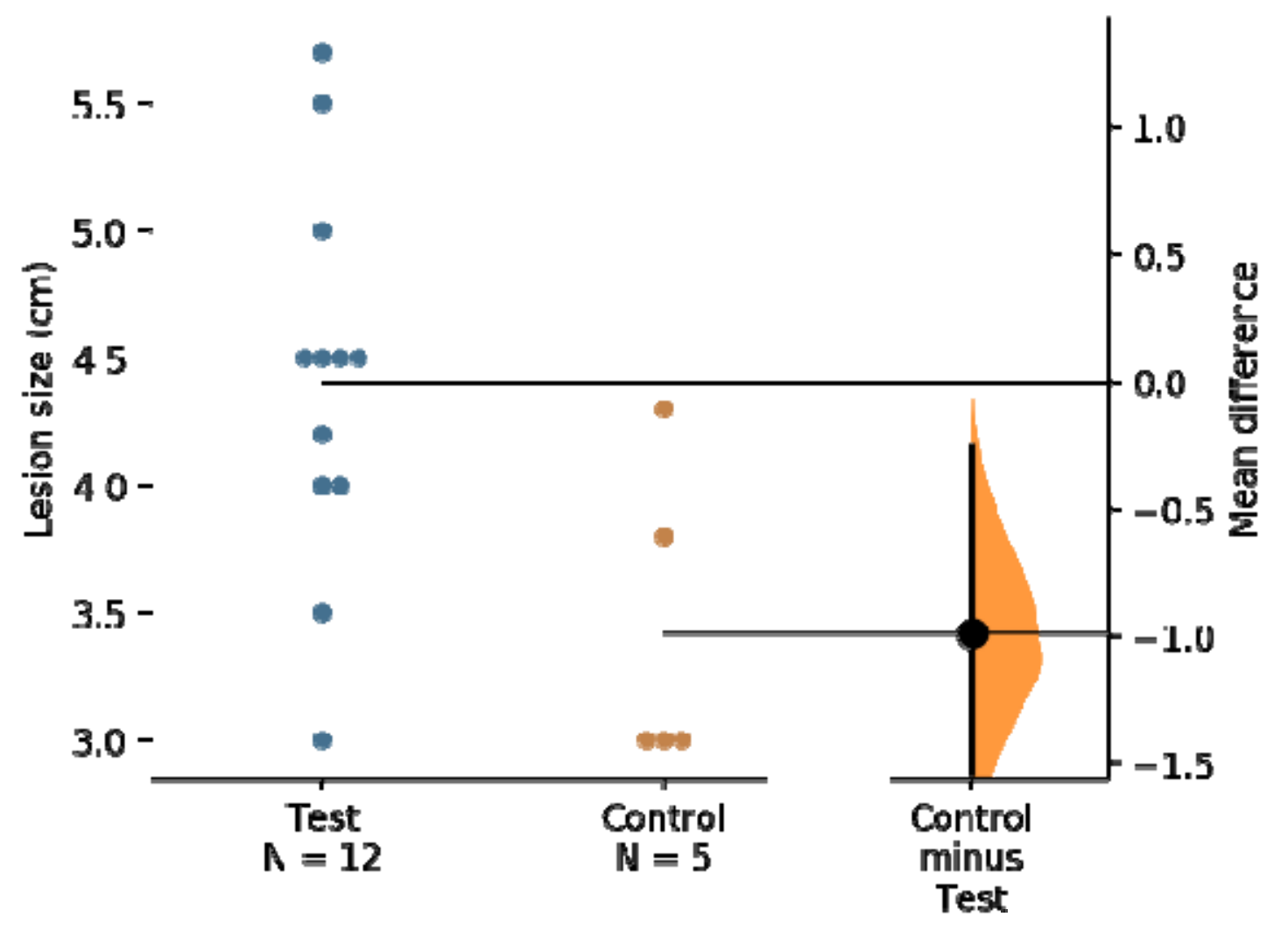

Figure 3 Estimation plots of data form the pathogenicity test. Saplings were inoculated with Phytophthora lacustris (test) or with sterile agar plugs (control). The filled curve indicates the complete difference in means distribution, given the observed data. The $95 \%$ confidence interval of difference in means is illustrated by the thick black line. The difference in means between the treatments (inoculation with $P$. lacustris or control) was significantly different based on a Mann Whitney $\mathrm{U}$ test $(\mathrm{U}=51.5, \mathrm{p}<0.05)$.

\section{Alder survey}

A total of 166 Alnus trees were surveyed along an $8.5 \mathrm{~km}$ stretch on one side of the Lagan. The majority ( $83 \%$ or 137 trees) had diameters greater than $10 \mathrm{~cm}$ (Supplementary table 1). Of the total number of alder, 121 had low defoliation (1 or 2), with 28 showing moderate to severe defoliation. Nine Alnus trees were dead. Nine of the trees had bleeding cankers, and all of these were in defoliation class 3 or 4 . Other tree species recorded were Fraxinus excelsior ( $\mathrm{n}=23)$, Salix spp. (14), Acer pseudoplatanus (9), Crataegus monogyna (8), Quercus spp. (5), Betula spp. (3), Fagus sylvatica (3) and Populus spp. (3). There was one tree each of Tilia cordata and Corylus avellana recorded.

\section{Discussion}

Alder dieback due to Phytophthora is currently widespread along river systems in many European countries including southern Germany (Jung and Blaschke 2004), Northern France (Thoirain et al. 2007), Czech Republic (Cerny and Strnadova 2010), Sweden (Redondo et al. 2015), and England (Webber et al. 2004). The disease is also present in several other countries in Europe (Jung et al. 2018), including Ireland (O'Hanlon et al. 2016a), though 
large scale surveys are needed to delimit its extent. The large scale death of Alnus in these river systems will likely have many negative impacts on the ecosystems services these trees provide (Cerny et al. 2008; Bjelke et al. 2016). Alder has many important functions in riparian habitats, including provision of shade, Nitrogen fixation, stabilization of river banks through its root network, provision of habitat for many organisms, and increasing the aesthetic appeal of river banks (Bjelke et al. 2016). In Ireland and Northern Ireland, it is the $6^{\text {th }}$ most commonly recorded tree species in the wild, after Crataegus spp., Fraxinus excelsior, Acer pseudoplatanus, Ilex aquifolium, and Prunus spinosa (National Biodiversity Data Centre 2019).

Jung et al. (2018) provide a comprehensive review of the distribution of Alnus decline in Europe. They highlight that although the main cause of the decline is usually either Phytophthora uniformis, the hybrid taxa Phytophthora $\times$ alni or Phytophthora $\times$ multiformis; other Phytophthora species are also known to cause disease in Alnus. These include Phytophthora cactorum, P. gonapodyides, P. lacustris, Phytophthora plurivora and Phytophthora polonica. This research has found that $P$. lacustris is possibly responsible for Alnus decline along the river Lagan in Belfast, Northern Ireland. Phytophthora lacustris has also been found infecting A. glutinosa in Portugal (Kanoun-Boule et al. 2016), as well as several other plant hosts in Europe (Nechwatal et al. 2013). The river baiting carried out in the study also indicates that there is a risk of $P$. lacustris spreading along the river and infecting more trees. This is similar to findings of P. lacustris in soil and streams in Ireland (O'Hanlon et al. 2016b). It is well known that Phytophthora species spread readily in water in commercial (Zappia et al. 2014) and wider environment (Sims et al. 2014) locations. Gibbs et al. (1999) also found evidence that Phytophthora disease of Alnus in England was being spread in the river. Worryingly, the low number of young Alnus trees recorded in the survey may indicate that $P$. lacustris is reducing recruitment of young Alnus trees, as well as killing older Alnus. Younger plants are known to be more susceptible to Phytophthora infection than older ones (Oßwald et al. 2014). This could lead to a situation where Alnus becomes less common along the river Lagan, thus reducing the ecosystem services provided by Alnus.

This study used a combination of morphotyping and DNA sequencing to identify the oomycete diversity. Unfortunately, the ITS primers used did not allow for resolution of the species to a high degree $(>99 \%)$ of confidence. There were also issues with the analysis returning two different species names of equal similarity to the morphotypes collected. O'Hanlon et al. (2016b) also discussed this issue, when their sequencing was unable to separate closely related taxa within Phytophthora clade 7. The use of several markers is encouraged to separate closely related species within the genus Phytophthora (Hyde et al., 2014; Yang and Hong 2018). The result of the DNA analyses also depended on the database used. With PhytophthoraID being a curated database including only sequences of deposited species confirmed by competent taxonomists (Grünwald, et al. 2011), this resource is likely to be more reliable and accurate. GenBank on the other hand is not curated, and is known to suffer from erroneous names of sequence deposits of other microorganisms (e.g. fungi; Nilsson, et al. 2006) in the database. It is highly likely that the four morphotypes identified from the baiting samples are $P$. gonapodyides, $P$. chlamydospore, $P$. lacustris and Phytopythium litorale, as suggested by the DNA sequencing. These species have been found in surveys in Ireland (O'Hanlon et al. 2016b), and also in other samples from watercourses in Northern Ireland (O'Hanlon 2017). They are also common in other regions of the world (Cerny et al. 2015; Duarte et al. 2015; Hansen et al. 2015). None of the species, except $P$. lacustris, is known as a threatening plant pathogen, and they probably function in speeding up the decay of plant material in streams (Hansen et al. 2012). 
It is interesting to speculate if, and how, $P$. lacustris may have entered the area. It is not known if $P$. lacustris is native to Ireland and Northern Ireland, with Jung et al. (2016) unable to assign its putative native range. The species has been linked with plant trade infrequently across Europe (Jung et al. 2016) and the USA (Bienapfl and Balci 2014), and therefore could have been introduced inadvertently into Northern Ireland on infected plant material or soil. The area of the Lagan surveyed in this research is highly modified by humans, with the nearby Belvoir forest area having a long history of history of exotic plant introductions. The riverbank also has a widespread infestation of Rhododendron ponticum, Japanese knotweed (Fallopia japonica), Giant Hogweed (Heracleum mantegazzianum), and Himalayan balsam (Impatiens glandulifera). The nearby Belvoir forest also has had recent infestations of other important Phytophthora species, including the regulated Phytophthora ramorum on Japanese larch (Larix kaempferi) and the previously regulated Phytophthora lateralis on Lawson Cypress (Chamaecyparis lawsoniana). Coupled with this, there has been an invasion and outbreak of the non-native insect pests horsechestnut leaf miner (Cameraria ohridella) on horsechestnut (Aesculus hippocastanum) (Anon 2014) and ash sawfly Tomostethus nigritus on ash F. excelsior in the area since 2016 (Jess et al. 2017).

This investigation is the first to demonstrate P. lacustris as a cause of disease in Alnus on the island of Ireland (i.e. in Northern Ireland or Ireland). Though we did not detect either of the other serious Phytophthora pathogens of Alnus, P. uniformis or P. $\times$ alni, it is also likely that they are responsible for Alnus decline in Northern Ireland, as these have been recorded in Alnus in Ireland (O'Hanlon et al. 2016a). The ecology of the river ecosystem of the river Lagan is under threat from Phytophthora and many other invasive species. Better biosecurity education will help prevent further introductions for invasive species to habitats in Ireland and Northern Ireland. There is also good potential to use regular river baiting and riparian tree surveys (or amateur records) as an early warning system for new plant pest invasions.

\section{Acknowledgements}

The authors acknowledge the Royal Society of Biology, DEFRA, BSPP and N8 AgriFood for funding JW on a Plant Health Studentship. The research was funded by the Department of Agriculture, Environment and Rural Affairs Northern Ireland.

\section{References}

Anon. 2014. Horse Chestnut Leaf-miner Cameraria ohridella present in Ireland. Available: http://www.mothsireland.com/?s=Cameraria+ohridella\&searchsubmit=

Bienapfl, J.C., Balci Y. 2014. Movement of Phytophthora spp. in Maryland's nursery trade. Plant Disease 98: 134-144.

Bjelke, U., Boberg, J., Oliva, J., Tattersdill, K. and McKie, B.G., 2016. Dieback of riparian alder caused by the Phytophthora alni complex: projected consequences for stream ecosystems. Freshwater biology, 61: 565-579.

Brasier, C.M., Kirk, S.A., Delcan, J., Cooke, D.E.L., Jung, T. and Man In't Veld, W.A. 2004 Phytophthora alni sp. nov. and its variants: designation of emerging heteroploid pathogens spreading on Alnus trees. Mycological Research 108: 1172-1184. 
Cerny $\square$ K, and Strnadová V. 2010. Phytophthora alder decline: disease symptoms, causal agent and its distribution in the Czech Republic. Plant Protection Science 46: 12-18.

Cerny, K., Gregorova, B., Strnadova, V., Holub, V., Tomsovsky, M. and Cervenka, M., 2008. Phytophthora alni causing decline of black and grey alders in the Czech Republic. Plant Pathology, 57(2).

Cerny, K., Strnadová, V., Romportl, D., Mrázková, M., Havrdová, L., Hrabětová, M., Modlinger, R. and Pešková, V. 2015. Factors Affecting Phytophthora alni Distribution in State Forests of the Czech Republic. In: Wendy Sutton, Paul W. Reeser and Everett M. Hansen Proceedings of the 7th Meeting of the

International Union of Forest Research Organizations

IUFRO Working Party 7-02-09 available: http://forestphytophthoras.org/sites/default/files/proceedings/IUFRO_Proceedings_2014.pdf

Clancy, K.J. and Hamilton, A.M. 2001 Phytophthora disease of alder. Society of Irish Plant Pathologists Newsletter 28.

Clapham, A.R., Tutin, T.G. and Warburg, E.F. 1952. Flora of the British Isles. University press, Cambridge.

Cross, J. 2012. Ireland's Native woodlands: A summary based on The National Survey of Native Woodlands. Irish Forestry 69: 73-95.

DAFM 2015. Forestry standards manual. Available: https://www.agriculture.gov.ie/media/migration/forestry/grantandpremiumschemes/2015/For estryStandManNov15050116.pdf

DAERA 2019 Forestry Grant Schemes Information Booklet Rural Development Programme $2014 \quad$-2020. Available https://www.daerani.gov.uk/sites/default/files/publications/daera/Forestry\%20Grant\%20Schemes\%20Informati on\%20Booklet\%202019-20.pdf

Deal, R.L., Hennon, P., O'Hanlon, R. and D'Amore, D., 2013. Lessons from native spruce forests in Alaska: managing Sitka spruce plantations worldwide to benefit biodiversity and ecosystem services. Forestry, 87: 193-208.

Duarte, S., Barlocher, F., Trabulo, J., Cassio, F. and Pascoal, C. 2015. Streamdwelling fungal decomposer communities along a gradient of eutrophication unraveled by 454 pyrosequencing. Fungal Diversity 70: 127-14.

Gallegly, M.E. and Hong, C., 2008. Phytophthora: Identifying species by morphology and DNA fingerprints. American Phytopathological Society (APS Press).

Gibbs, J.N., Lipscombe, M.A. and Peace, A.J. 1999. The impact of Phytophthora disease on riparian populations of common alder (Alnus glutinosa) in southern Britain. European Journal of Forest Pathology 29: 39-50.

Grünwald, N. J., Martin, F. N., Larsen, M. M., Sullivan, Press, C. M., Coffey, M. D., Hansen, E. M., and Parke, J. L. 2011. Phytophthora-ID.org: A sequence-based Phytophthora identification tool. Plant Disease 95: 337-342.

Hansen, E.M., Reeser, P.W., Sutton, W. 2012. Phytophthora beyond agriculture. Annual Review of Phytopathology 50: 359-378. 
Ho, J., Tumkaya, T., Aryal, S., Choi, H. and Claridge-Chang, A., 2019. Moving beyond P values: data analysis with estimation graphics. Nature Methods, p.1.

Horgan, T., Keane, M., McCarthy, R., Lally, M., Thompson, D. 2004. A guide to forest tree species selection and silviculture in Ireland. Dublin: COFORD

Husson, C., Aguayo, J., Revellin, C., Frey, P., Ioos, R. and Marcais, B. 2015 Evidence for homoploid speciation in Phytophthora alni supports taxonomic reclassification in this species complex. Fungal Genetics and Biology 77: 12-21.

Hyde, K.D., Nilsson, R.H., Alias, S.A., Ariyawansa, H.A., Blair, J.E., Cai, L., de Cock, A.W., Dissanayake, A.J., Glockling, S.L., Goonasekara, I.D. and Gorczak, M., 2014. One stop shop: backbones trees for important phytopathogenic genera: I (2014). Fungal Diversity, 67: 21-125.

Jess, S., Murchie, A., Allen, D. and Crory, A., 2017. First observation of Tomostethus nigritus (Fabricius)(Hymenoptera: Tenthredinidae) on urban ash trees in Ireland. Irish Naturalists' Journal, 35: 134-136.

Jung, T., Pérez-Sierra, A., Durán, A., Horta Jung, M., Balci, Y., Scanu B, 2018. Canker and decline diseases caused by soil and airborne Phytophthora species in forests and woodlands. Persoonia 40: 182-220.

Jung, T., Orlikowski, L., Henricot, B., Abad-Campos, P., Aday, A.G., Aguín Casal, O., Bakonyi, J., Cacciola, S.O., Cech, T., Chavarriaga, D., Corcobado, T., Cravador, A., Decourcelle, T., Denton, G., Diamandis, S., Doğmuş-Lehtijärvi, H.T., Franceschini, A., Ginetti, B., Green, S., Glavendekić, M., Hantula, J., Hartmann, G., Herrero, J., Ivic, D., Horta Jung, M., Lilja, A., Keca, N., Kramarets, V., Lyubenova, A., Machado, H., Magnano di San Lio, G., Mansilla Vázquez, P.J., Marçais, B., Matsiakh, I., Milenkovic, I., Moricca, S., Nagy, Z.A., Nechwatal, J., Olsson, C., Oszako, T., Pane, A., Paplomatas, E.J., Pintos Varela, C., Prospero, S., Rial Martínez, C., Rigling, D., Robin, C., Rytkönen, A., Sánchez, M.E., Sanz Ros, A.V., Scanu, B., Schlenzig, A., Schumacher, J., Slavov, S., Solla, A., Sousa, E., Stenlid, J., Talgø, V., Tomic, Z., Tsopelas, P., Vannini, A., Vettraino, A.M., Wenneker, M., Woodward, S. and Peréz-Sierra A. 2016 Widespread Phytophthora infestations in European nurseries put forest, semi-natural and horticultural ecosystems at high risk of Phytophthora diseases. Forest Pathology doi: 10.1111/efp.12239.

Jung, T. and Blaschke, M., 2004. Phytophthora root and collar rot of alders in Bavaria: distribution, modes of spread and possible management strategies. Plant Pathology. 53: 197208.

Kanoun $\square$ Boulé, M., Vasconcelos, T., Gaspar, J., Vieira, S., Dias $\square$ Ferreira, C. and Husson, C., 2016. Phytophthorax alni and Phytophthora lacustris associated with common alder decline in Central Portugal. Forest Pathology, 46: 174-176.

Lakatos, F., Mirtchev, S., Mehmeti, A. and Shabanaj, H., 2014. Manual for visual assessment of forest crown condition. Editorial Staff, FAO, Pristina, Kosovo.

Mitchell, A. 1996. Trees of Britain. Collins, England.

National Biodiversity Data Centre, Ireland (2019) Alder (Alnus glutinosa), accessed 17 July 2019, available https://maps.biodiversityireland.ie/Species/39578

Nechwatal, J., Bakonyi, J., Cacciola, S.O., Cooke, D.E.L., Jung, T., Nagy, Z.Á., Vannini, A., Vettraino, A.M., and Brasier, C.M. 2013. The morphology, behaviour and molecular 
phylogeny of Phytophthora taxon Salixsoil and its redesignation as Phytophthora lacustris sp. nov. Plant Pathology 62: 355-369.

NFI 2017 Ireland's National Forest Inventory. Available at: https://www.agriculture.gov.ie/nfi/nfithirdcycle2017/ (accessed 17 July 2019).

Nilsson, R.H., Ryberg, M., Kristiansson, E., Abarenkov, K., Larsson, K.H. and Kõljalg, U., 2006. Taxonomic reliability of DNA sequences in public sequence databases: a fungal perspective. PloS one, 1(1), p.e59.

O'Hanlon, R. (2017) Monitoring for threatening plant pathogens in Northern Ireland. EPPO workshop on tools for inspectors, 13/12/17. Available: https://www.eppo.int/media/uploaded_images/MEETINGS/Meetings_2017/inspectors/09_O

Hanlon.pdf

O’Hanlon R, Choiseul J, Corrigan M, Catarame T, Destefanis M, 2016b. Diversity and detections of Phytophthora species from trade and non-trade environments in Ireland. EPPO Bulletin 46, 594-602.

O'Hanlon R, McCracken AR, Cooke LR, 2016a. Diversity and ecology of Phytophthora species on the island of Ireland. Biology and Environment 116B 27-52.

O'Hanlon, R., Choiseul, J., Brennan, J.M. and Grogan, H., 2018. Assessment of the eradication measures applied to Phytophthora ramorum in Irish Larix kaempferi forests. Forest Pathology, 48(1), p.e12389.

Oßwald, W., Fleischmann, F., Rigling, D., Coelho, A.C., Cravador, A., Diez, J., Dalio, R.J., Horta Jung, M., Pfanz, H., Robin, C. and Sipos, G., 2014. Strategies of attack and defence in woody plant-P hytophthora interactions. Forest Pathology, 44: 169-190.

Redondo, M.A., Boberg, J., Olsson, C.H. and Oliva, J., 2015. Winter conditions correlate with Phytophthora alni subspecies distribution in Southern Sweden. Phytopathology, 105: 1191-1197.

Scanu, B., Linaldeddu, B.T., Deidda, A. and Jung, T., 2015. Diversity of Phytophthora species from declining Mediterranean maquis vegetation, including two new species, Phytophthora crassamura and P. ornamentata sp. nov. PLoS One, 10(12), p.e0143234.

Sims, L.L., Sutton, W., Reeser, P., and Hansen, E.M. 2015. The Phytophthora species assemblage and diversity in riparian alder ecosystems of western Oregon, USA. Mycologia 107: 889-902.

Streito, J.C., 2003. Phytophthora disease of alder: identification and distribution. Forestry Commission Bulletin, (126), pp.25-38.

Thoirain, B., Husson, C., Marçais, B. 2007. Risk factors for the Phytophthora-induced decline of alder in north-eastern France. Phytopathology 97: 99-105.

Turner, J., Jennings, P., Humphries, G., \& Lockley, D. 2006. Epidemiology of natural outbreaks of Phytophthora ramorum. Project Report PH0195. Sand Hutton, York, UK: Forest Research. On file with: Central Science Laboratory, Department for Environment, Food and Rural Affairs, Sand Hutton, York.

Webber, J., Gibbs, J. and Hendry, S., 2004. Phytophthora disease of alder (No. 6 Revised, pp. 1-6). Forestry Commission. 
Werres, S., Marwitz, R., Man In't Veld, W.A., De Cock, W.A.M., Bonants, P.J.M., De Weert, M., Themann, K., Ilieva, E., Baayen, R.P. 2001. Phytophthora ramorum sp. Nov., a new pathogen on Rhododendron and Viburnum. Mycological Research 105 1155-1165.

White, T.J., Bruns, T., Lee, S., Taylor, J.W. (1990) Amplification and direct sequencing of fungal ribosomal RNA genes for phylogenetics. In Innis MA, Gelfand DH, Sninsky JJ, White TJ (eds) PCR Protocols: A Guide to Methods and Applications. New York: Academic Press Inc

Yang, X. and Hong, C., 2018. Differential usefulness of nine commonly used genetic markers for identifying Phytophthora species. Frontiers in microbiology, 9, p.2334.

Zappia, R.E., Huberli, D., Hardy, G.E. St and Bayliss, K.E. 2014 Fungi and oomycetes in open irrigation systems: knowledge gaps and biosecurity implications. Plant Pathology 63: 961-972.

Supplementary table 1 Alnus tree health survey results. The level crown defoliation class ( $1=$ low defoliation, $4=$ extensive defoliation; Lakatos et al. 2014), age group (1= Diameter at Breast Height $(\mathrm{DBH})<10 \mathrm{~cm}, 2=\mathrm{DBH} 10-20,3=\mathrm{DBH}>20)$ and the presence of cankers for every Alnus tree was recorded. Notes were also taken of other tree health aspects for the surveyed Alnus trees.

\begin{tabular}{|l|l|l|l|l|}
\hline $\begin{array}{l}\text { Alder } \\
\text { identifier }\end{array}$ & $\begin{array}{l}\text { Defoliation } \\
\text { class score }\end{array}$ & Age & $\begin{array}{l}\text { Presence } \\
\text { of cankers }\end{array}$ & notes \\
\hline A1 & 4 & 2 & 0 & \\
\hline A2 & 0 & 2 & 0 & \\
\hline A3 & 1 & 2 & 0 & \\
\hline A4 & 3 & 2 & 1 & \\
\hline A5 & 3 & 2 & 1 & \\
\hline A6 & 0 & 2 & 0 & \\
\hline A7 & 0 & 1 & 0 & \\
\hline A8 & 0 & 2 & 0 & \\
\hline A9 & 0 & 2 & 0 & \\
\hline
\end{tabular}




\begin{tabular}{|c|c|c|c|c|}
\hline A10 & 4 & 1 & 1 & \\
\hline A11 & 0 & 2 & 0 & \\
\hline A12 & 0 & 1 & 0 & \\
\hline A13 & 2 & 2 & 0 & \\
\hline A14 & 0 & 2 & 0 & \\
\hline A15 & 0 & 2 & 0 & \\
\hline A16 & 0 & 3 & 0 & \\
\hline A17 & 0 & 2 & 0 & \\
\hline A18 & 0 & 2 & 0 & \\
\hline A19 & 0 & 2 & 0 & \\
\hline A20 & 0 & 2 & 0 & \\
\hline A21 & 0 & 3 & 0 & \\
\hline A22 & 0 & 2 & 0 & \\
\hline A23 & 3 & 2 & 0 & \\
\hline A24 & 2 & 2 & 0 & \\
\hline A25 & 0 & 2 & 0 & \\
\hline A26 & 0 & 2 & 0 & \\
\hline A27 & 0 & 2 & 0 & \\
\hline A28 & 0 & 2 & 0 & \\
\hline A29 & 0 & 2 & 0 & \\
\hline A30 & 2 & 2 & 0 & Galls \\
\hline A31 & 0 & 2 & 0 & \\
\hline A32 & 0 & 2 & 0 & \\
\hline A33 & 0 & 2 & 0 & \\
\hline A34 & 0 & 2 & 0 & \\
\hline A35 & 0 & 2 & 0 & \\
\hline A36 & 0 & 2 & 0 & \\
\hline A37 & 0 & 2 & 0 & \\
\hline A38 & 3 & 2 & 0 & almost dead \\
\hline A39 & 0 & 3 & 0 & \\
\hline A40 & 4 & 3 & 0 & lots of bracket fungi \\
\hline A41 & 0 & 2 & 0 & \\
\hline A42 & 0 & 2 & 0 & \\
\hline A43 & 0 & 2 & 0 & \\
\hline A44 & 0 & 2 & 0 & \\
\hline A45 & 0 & 2 & 0 & \\
\hline A46 & 0 & 2 & 0 & \\
\hline A47 & 0 & 2 & 0 & \\
\hline A48 & 0 & 2 & 0 & \\
\hline A49 & 0 & 2 & 0 & \\
\hline A50 & 3 & 2 & 0 & dead \\
\hline A51 & 3 & 2 & 0 & dead \\
\hline A52 & 3 & 2 & 0 & dead \\
\hline A53 & 4 & 2 & 0 & \\
\hline
\end{tabular}




\begin{tabular}{|c|c|c|c|c|}
\hline A54 & 4 & 2 & 0 & ivy present \\
\hline A55 & 0 & 2 & 0 & \\
\hline A56 & 0 & 2 & 0 & \\
\hline A57 & 0 & 2 & 0 & \\
\hline A58 & 0 & 2 & 0 & \\
\hline A59 & 0 & 2 & 0 & \\
\hline A60 & 0 & 2 & 0 & \\
\hline A61 & 0 & 3 & 0 & \\
\hline A62 & 0 & 3 & 0 & \\
\hline A63 & 3 & 3 & 0 & Dead on one side \\
\hline A64 & 0 & 1 & 0 & \\
\hline A65 & 0 & 1 & 0 & \\
\hline A66 & 3 & 3 & 1 & $\begin{array}{l}\text { dead crown. Girdled stem, } \\
\text { galls }\end{array}$ \\
\hline A67 & 0 & 1 & 0 & \\
\hline A68 & 1 & 1 & 0 & \\
\hline A69 & 3 & 3 & 1 & mostly in the river \\
\hline A70 & 3 & 1 & 0 & almost dead \\
\hline A71 & 0 & 1 & 0 & \\
\hline A72 & 0 & 1 & 0 & \\
\hline A73 & 1 & 3 & 0 & Ivy present \\
\hline A74 & 0 & 1 & 0 & \\
\hline A75 & 0 & 1 & 0 & \\
\hline A76 & 0 & 1 & 0 & \\
\hline A77 & 0 & 1 & 0 & \\
\hline A78 & 0 & 1 & 0 & \\
\hline A79 & 0 & 1 & 0 & \\
\hline A80 & 0 & 1 & 0 & \\
\hline A81 & 1 & 1 & 0 & \\
\hline A82 & 0 & 2 & 0 & \\
\hline A83 & 0 & 3 & 0 & \\
\hline A84 & 0 & 2 & 0 & \\
\hline A85 & 3 & 1 & 1 & \\
\hline A86 & 1 & 3 & 0 & \\
\hline A87 & 1 & 1 & 0 & \\
\hline A88 & 0 & 1 & 0 & \\
\hline A89 & 0 & 2 & 0 & \\
\hline A90 & 2 & 1 & 0 & \\
\hline A91 & 0 & 2 & 0 & \\
\hline A92 & 2 & 1 & 0 & \\
\hline A93 & 1 & 2 & 0 & \\
\hline A94 & 2 & 2 & 0 & \\
\hline A95 & 0 & 2 & 0 & \\
\hline A96 & 0 & 2 & 0 & \\
\hline A97 & 0 & 2 & 0 & \\
\hline
\end{tabular}




\begin{tabular}{|c|c|c|c|c|}
\hline A98 & 2 & 2 & 0 & \\
\hline A99 & 0 & 3 & 0 & \\
\hline A100 & 0 & 2 & 0 & \\
\hline A101 & 0 & 2 & 0 & \\
\hline A102 & 0 & 2 & 0 & \\
\hline A103 & 0 & 2 & 0 & \\
\hline A104 & 0 & 2 & 0 & \\
\hline A105 & 0 & 2 & 0 & \\
\hline A106 & 0 & 2 & 0 & \\
\hline A107 & 0 & 2 & 0 & \\
\hline A108 & 0 & 2 & 0 & \\
\hline A109 & 0 & 2 & 0 & \\
\hline A110 & 0 & 2 & 0 & \\
\hline A111 & 0 & 2 & 0 & \\
\hline A112 & 0 & 2 & 0 & \\
\hline A113 & 0 & 2 & 0 & \\
\hline A114 & 0 & 2 & 0 & \\
\hline A115 & 0 & 2 & 0 & \\
\hline A116 & 0 & 2 & 0 & \\
\hline A117 & 0 & 2 & 0 & \\
\hline A118 & 0 & 2 & 0 & \\
\hline A119 & 0 & 1 & 0 & \\
\hline A120 & 0 & 2 & 0 & \\
\hline A121 & 0 & 3 & 0 & \\
\hline A122 & 0 & 3 & 0 & \\
\hline A123 & 2 & 2 & 0 & Ivy present, tree $40 \%$ dead \\
\hline A124 & 1 & 2 & 0 & \\
\hline A125 & 0 & 2 & 0 & \\
\hline A126 & 0 & 2 & 0 & \\
\hline A127 & 0 & 2 & 0 & \\
\hline A128 & 2 & 2 & 0 & \\
\hline A129 & 0 & 2 & 0 & \\
\hline A130 & 0 & 2 & 0 & \\
\hline A131 & 0 & 2 & 0 & \\
\hline A132 & 0 & 2 & 0 & \\
\hline A133 & 0 & 2 & 0 & \\
\hline A134 & 0 & 2 & 0 & \\
\hline A135 & 0 & 2 & 0 & \\
\hline A136 & 0 & 2 & 0 & \\
\hline A137 & 0 & 2 & 0 & \\
\hline A138 & 0 & 2 & 0 & \\
\hline A139 & 0 & 2 & 0 & \\
\hline A140 & 0 & 2 & 0 & \\
\hline A141 & 0 & 2 & 0 & \\
\hline
\end{tabular}


bioRxiv preprint doi: $\mathrm{https}$ //doi.org/10.1101/2019.12.13.875229; this version posted December 13,2019 . The copyright holder for this preprint (which was not certified by peer review) is the author/funder, who has granted bioRxiv a license to display the preprint in perpetuity. It is made available under aCC-BY-NC 4.0 International license.

\begin{tabular}{|l|l|l|l|l|}
\hline A142 & 0 & 2 & 0 & \\
\hline A143 & 0 & 2 & 0 & \\
\hline A144 & 0 & 2 & 0 & \\
\hline A145 & 2 & 2 & 0 & \\
\hline A146 & 3 & 2 & 0 & \\
\hline A147 & 0 & 2 & 0 & \\
\hline A148 & 0 & 2 & 0 & \\
\hline A149 & 0 & 2 & 0 & \\
\hline A150 & 2 & 2 & 0 & \\
\hline A151 & 0 & 1 & 0 & \\
\hline A152 & 4 & 2 & 0 & \\
\hline A153 & 2 & 2 & 0 & \\
\hline A154 & 2 & 2 & 0 & \\
\hline A155 & 0 & 1 & 0 & \\
\hline A156 & 0 & 1 & 0 & \\
\hline A157 & 3 & 2 & 0 & almost dead \\
\hline A158 & 0 & 2 & 0 & \\
\hline A159 & 0 & 2 & 0 & \\
\hline A160 & 0 & 2 & 0 & \\
\hline A161 & 2 & 3 & 0 & \\
\hline A162 & 0 & 1 & 0 & \\
\hline A163 & 0 & 1 & 0 & \\
\hline A164 & 4 & 2 & 1 & \\
\hline A165 & 4 & 2 & 1 & \\
\hline A166 & 4 & 2 & 1 & \\
\hline
\end{tabular}

